\title{
11
}

\section{The Western Route Migration: A Second Probable Neolithic Diffusion to Indonesia}

\author{
Truman Simanjuntak
}

The emergence of the Neolithic is considered to be a pivotal event in the history of human occupation of the Indonesian archipelago as it brought significant changes in numerous aspects of livelihood. Indonesia's Neolithic was characterised by sedentary living, plant and animal domestication, polished stone tools, pottery, jewellery, bark cloth and ancestor worship. The Neolithic in Indonesia is generally traced to the culture of Austronesian-speaking people who migrated from Taiwan and entered the archipelago at ca. 4000 BP. However, new data from various disciplines reveal another probable Neolithic diffusion from Mainland Southeast Asia, probably by Austroasiatic-speaking people. Current dating results indicate this westerly migration route reached western Indonesia earlier than the eastern route migration from Taiwan, thus before 4000 BP. The subsequent dispersal of Austronesian-speaking people into the western parts of Indonesia influenced the Neolithic cultures there and resulted in the replacement of the local Austroasiatic languages.

\section{Introduction}

One of Peter Bellwood's great archaeological interests is in the emergence and expansion of food production and the Neolithic, which he initially investigated across the Pacific and Southeast Asia (Bellwood 1978) before focusing on Island Southeast Asia (Bellwood 1984-1985, 1985) and then moving onto a worldwide perspective (Bellwood 2005). In Island Southeast Asia (ISEA) Peter's research has focused on the relationship between the migration of early farming communities and the origins of the Austronesian language families spoken ethnographically by large numbers of people across the region. He wavered on the question of whether or not there may have been some involvement of early Austoasiatic speakers from Mainland Southeast Asia (MSEA) in the Neolithic foundations of ISEA (Bellwood 1997, 2006). For example, Bellwood (1997: 237) noted that the material culture recovered from the site of Gua Sireh in Sarawak, Malaysian Borneo, had more in common with the Peninsular Malaysian and southern Thai Neolithic than it did with eastern Indonesia, and that the archaeological record correlated neatly with Adelaar's (1995) argument for a substratum of Austroasiatic in the Land Dayak languages of western Sarawak. The possible migration of Neolithic Austroasiatic populations from MSEA into western Indonesia is the topic that this contribution explores. 


\section{Neolithic and Austronesian}

The development of Neolithic culture brought immense changes to people's daily life across numerous aspects of technology, economy and social organisation, and is considered to be a major event in the pathways to civilisation (Simanjuntak 1992). The main factor that triggered this development is sedentary lifeways. By establishing permanent settlements, people were able to dedicate time to experimenting with new ideas and enriching their material culture and developing economic strategies. For instance, the concept of ensuring a reliable food supply led to strategic plant and animal domestication. Likewise, the concept of using more effective equipment in daily activities encouraged the use of tough, resistant stone that required polishing in lieu of flaking to produce stone tools. Social mechanisms for internal harmony allowed larger social groupings to reside together for longer periods of time. Furthermore, the idea that individuals retained their identity after death fostered the notion that the ancestors maintained a watchful eye over the present-day community, as manifested in respectful treatment of the dead. The rapid changes in cultural behaviour, economies and associated ideologies led Gordon Childe to coin the term the 'Neolithic Revolution' (Childe 1936).

How about the Neolithic in Indonesia? When, by whom, from where it emerged and how it developed constitute a set of intriguing questions that have not been fully and conclusively answered in our efforts to fully understand more about Indonesia's ancestors and their culture. The following discussion and interpretation is preliminary, and based on our current understanding of available linguistic, genetic and archaeological data.

Indonesia's distinctive culture is characterised by sedentary life in communities that also domesticated certain animals and plants; making polished stone tools, pottery, jewellery from various materials and bark cloth; adherence to metaphysical beliefs manifested in the burial systems; and the ability to sail, which facilitated settlement across the large area of the archipelago. I link 'Indonesia's ancestors' with the Neolithic because the Neolithic forebears brought this distinctive culture with them when they entered the archipelago thousands of years ago, and then have continued to occupy the archipelago up to the present. Briefly, I would say that the Neolithic is the real foundation stone of contemporary Indonesian culture. It is worth noting that the bearers of the Neolithic culture in Indonesia are generally associated with Austronesian-speaking people (hereafter named Austronesians). This 'Mongoloid' people entered the archipelago at ca. 4000 BP (Simanjuntak 2008).

This view is based on the 'Out-of-Taiwan' model explaining the migration of Austronesians and their Neolithic culture to ISEA (Bellwood 1984-1985, 1997; Bellwood et al. 1995), utilising archaeological and linguistic data, following similar views proposed by Blust (1984-1985) and Chang (1964) on the origin of the Austronesians in Taiwan. Their ancestors lived in Neolithic communities in Fujian or Zhejiang, South China, in about 7000-6000 BP. In $c a$. 6000-5500 $\mathrm{BP}$ they migrated to Taiwan and brought grain and tuber agriculture, pig and dog domestication, and knowledge of water navigation. In ca. 4500-4000 BP some of them moved southward to the northern Philippines and gave rise to the Proto-Malayo-Polynesian language, bringing with them agriculture, more advanced sailing technology and red-slipped pottery. The southward movement went via the southern Philippines, reached Kalimantan (Borneo) and Sulawesi and then continued to Java, Sumatra, Malay Peninsula, southern Vietnam and Madagascar (all areas that are linguistically Western Malayo-Polynesian). An eastward movement through the Moluccas to reach the Lesser Sundas (linguistically Central Malayo-Polynesian), and through Halmahera (linguistically Eastern Malayo-Polynesian) to reach Island Melanesia and Polynesia (linguistically Oceanic). In Western Melanesia, Austronesians moved mainly along the coast and never penetrated deeply into the interior of larger islands, at least partly due to the prior establishment of agricultural or arboricultural communities. 
The 'Out-of-Taiwan' model outlined above would invoke Sulawesi as an initial point of arrival for Austronesians into the modern sociopolitical region of Indonesia. There is archaeological evidence to support this view, in the form of early Neolithic sites such as Minanga Sipakko on a bank of the Karama River at Kalumpang, West Sulawesi. Minanaga Sipakko, characterised by an abundance of red-slipped potsherds in the lower occupation layer and the most richly decorated pottery in Southeast Asia in the upper layer (Bulbeck and Nasruddin 2002; Simanjuntak 2008; Anggraeni et al. 2014), was occupied by Austronesians between $c a .3800$ BP (3446 \pm 51 BP or cal. 3834-3572 BP (Wk-14651)) and ca. 2500 BP. It is possible that Austronesians entered Sulawesi as early as $c a .4000 \mathrm{BP}$, considering the location of Minanga Sipakko in a mountainous area in the hinterland of Sulawesi. Several other early sites in the region are Leang Tuwo Mane'e in the Sangihe-Talaud Islands, North Sulawesi, ca. 3600 BP (Tanudirjo 2001) and cave sites in the Maros-Pangkep area, ca. 3500 BP (Bulbeck 1996/1997). From Sulawesi, the Austronesians dispersed to other islands and by $c a .2500 \mathrm{BP}$ occupied most of the Indonesian archipelago.

\section{Western Route Migration evidence}

Until recently, there were some views on the homeland of Austronesian that opposed the 'Out-of-Taiwan' model (see Anceaux 1965; Tanudirjo and Simanjuntak 2004). These included Isidore Dyen's (1965) lexico-statistical analysis, which suggested a homeland in Melanesia; a proposal for the northeast Indonesia-Southern Philippines areas (Solheim 1984-1985); the former Pleistocene sub-continent of Sundaland (Oppenheimer 1998; Oppenheimer and Richards 2001); and the triangle of Taiwan-Sumatra-Timor (Meacham 1984-1985). This debate appears to have been resolved in favour of unanimous scholarly acceptance of Taiwan as the place of origin of the Austronesians. However, what is less clear is whether the Austronesians were the only people to introduce the Neolithic to Indonesia.

An important consideration is that ancient migration routes may be more complicated than single unidirectional pathways. Routes of migration could have had several departure and arrival points and been used multiple times, perhaps even involving movement back and forth, though to explain the wide geographic distributions of language families such as Austronesian there must have been some overall directionality away from the point of origin. In ISEA there is now evidence to suggest another route of migration besides the 'Out-of-Taiwan' model, from MSEA, and Vietnam, through Peninsular Malaysia and entering western Indonesia via Sumatra, before expanding into Borneo and Java (Figure 11.1; see also Anderson 2005). I will refer to this migration as the Western Route Migration (WRM) in order to distinguish it from the Eastern Route Migration (ERM) from Taiwan. Blench (2010) traces the WRM from northern Vietnam through Borneo and Palawan, before proceeding to Peninsular Malaysia and Sumatra. Regardless of which route is accurate (further research is required), those proposals recognise another route besides that from Taiwan. 


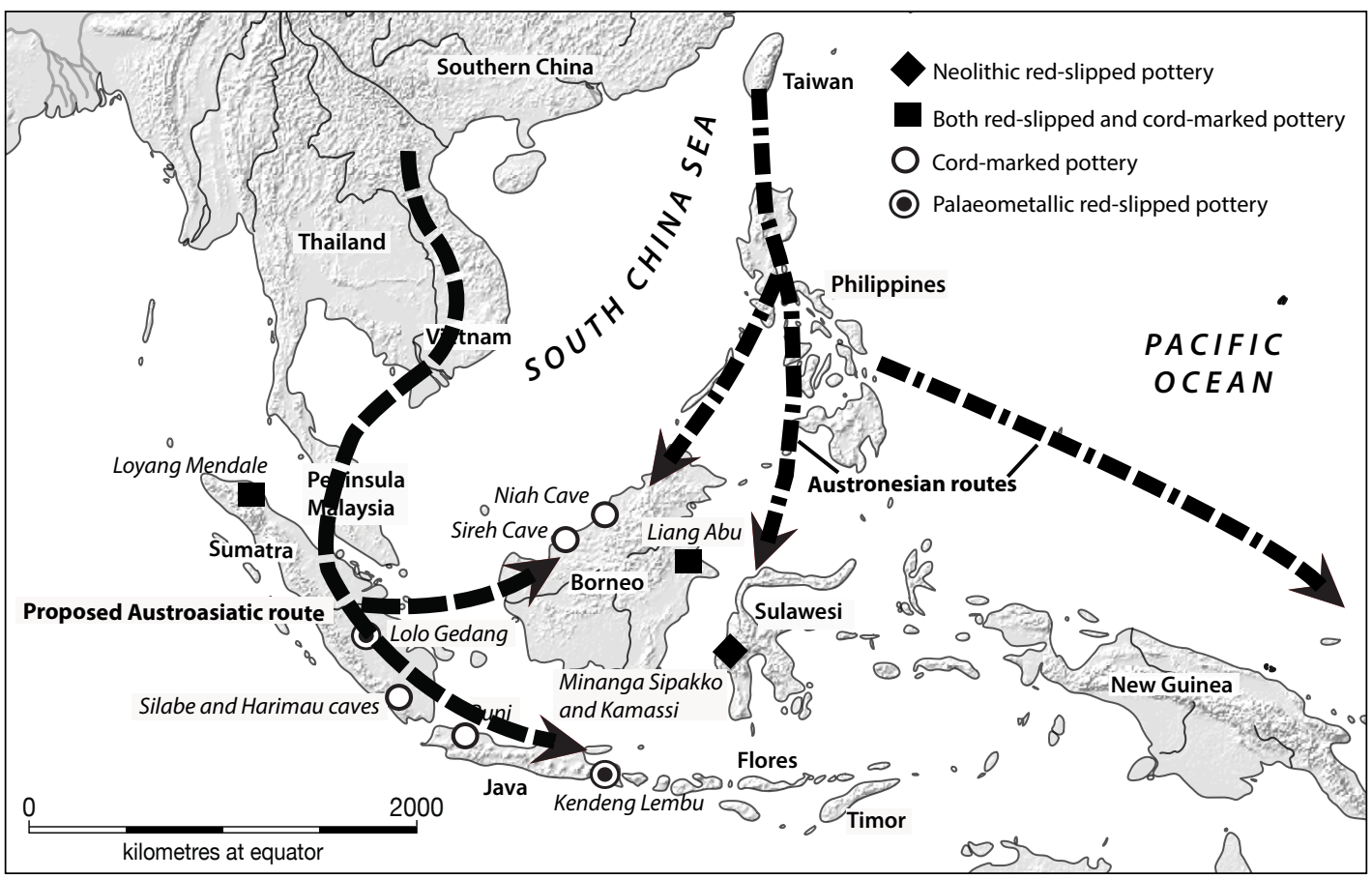

Figure 11.1 The proposed route of Austroasiatic and Austronesian migration into Indonesia and the geographic distribution of sites that have produced red-slipped and cord-marked pottery discussed in the text.

Source: Base map Peter Bellwood/ANU Cartography; Illustration courtesy of Philip Piper.

In a sense, the WRM is not a new idea, it was first proposed by scholars as early as the late nineteenth century, but without well-grounded empirical support. For example, in 1889 Hendrik Kern, a linguist, assigned the languages of the archipelago and remote Pacific to a Malayo-Polynesian group, with an ancestral homeland in MSEA, western Indonesia or South China (see Anceaux 1965). A decade later, W. Schmidt introduced the term 'Austronesian' to substitute for Kern's term 'Malayo-Polynesian', and traced the origins of Austronesian specifically to the Asia mainland. According to Schmidt, an ancestral Austric language, spoken on mainland Asia, split into the Austroasiatic languages spoken by mainland Asians (Mon-Khmer in IndoChina and Munda in India) and the Austronesian languages spoken by Indonesian and Pacific Islanders (Anceaux 1965). The proposals of these linguists were corroborated by archaeologists, such as van Stein Callenfels (1926), Heine-Geldern (1945) and Duff (1970). Heine-Geldern for instance claimed that the dispersal of quadrangular adzes might have originated in South China, and then moved southward through Indochina and the Malay Peninsula before reaching Indonesia at $c a .4000 \mathrm{BP}$.

This perspective proposed by early scholars regained its popularity with the support of new evidence from recent studies of various disciplines. Similarities in material culture, language and human biology reveal interconnections between MSEA and Sumatra, Kalimantan and Java in western Indonesia (Simanjuntak 2013). The archaeological evidence includes the geographic distribution of paddle-impressed pottery, especially the use of textile-wrapped paddles to produce what is often referred to as cord-marked pottery - one of the markers of the early Neolithic. This particular type of decoration is essentially limited to western Indonesia, including Loyang Mendale cave in Aceh (Wiradnyana and Taufikurrachman 2011), the Silabe and Harimau Caves in South Sumatra (Simanjuntak 2013), Buni on the north coast of West Java (Sutayasa 1972), and Liang Abu and some other sites in Kalimantan (Plutniak et al. 2014), extending to Gua Sireh and the Niah Caves in Sarawak, Malaysia. To date there are no reports of the presence 
of cord-marked pottery in eastern Indonesian Neolithic sites. To the north, cord-marked pottery is found in Neolithic sites in Vietnam (Masanari and Dung 2002), Peninsular Malaysia (Jaafar 2003), South China (Jiao 2004), Hong Kong (Meacham 1999) and Taiwan (Chang 1970). In contrast, red-slipped pottery, the marker of the 'Out-of-Taiwan' migration, is commonly found in Neolithic sites in or near the eastern parts of Indonesia (Spriggs 1989, 2011; Bellwood et al. 1998; Simanjuntak 2008; Galipaud et al. 2010; Simanjuntak et al. 2012; Anggraeni et al. 2014; O'Connor 2015). Red-slipped pottery is also found in the western parts of Indonesia, but so far limited to Palaeometallic and historical sites. Some archaeological sites containing red-slipped pottery are Kendenglembu in East Java (Noerwidi 2009), Liang Abu in Kalimantan (Plutniak et al. 2014) and Lolo Gedang in Jambi (Aziz 2009). Several examples are also reported from Loyang Mendale Cave, Aceh found together with three-coloured pottery (Wiradnyana and Taufiqurrahman 2011), but their stratigraphic associations still need verification.

It is important to note that the finding of both cord-marked and red-slipped pottery at the sites of Liang Abu and Loyang Mendale might suggest possible contacts between the two cultural streams. Indeed, proposals that would link the decorated pottery in Vietnam and eastern ISEA have a lengthy history in Southeast Asian archaeology. According to Heekeren (1950), HeineGeldern viewed Samrong Sen in Cambodia as the closest parallel for the decorated pottery at Kamassi, a Neolithic settlement near Minanga Sipakko in the Karama Valley region of Sulawesi. For his part, Heekeren (1972) concluded that the pottery designs at Kamassi were derived from the Sa-Huynh culture of Central Vietnam. Kamassi is now dated to ca. 3500 BP (Anggraeni et al. 2014) and clearly much older than Sa Huynh. Solheim (e.g. 1984-1985) noted further systematic similarities that the decorated pottery from the southern Philippines and Kalimantan exhibit with the decorated pottery from Vietnam and several parts of Thailand, which he attributed to a widespread 'Sa-Huynh Kalanay' tradition. Solheim further proposed that this shared tradition reflected the formation of a 'Nusantao' trading network in operation in the area of the South China Sea since 7000 BP, but this dating seems very early in the light of current archaeological evidence, and the Sa-Huynh Kalanay tradition is perhaps best viewed as reflecting an intensification of maritime trade during the late Neolithic and Palaeometallic (Bellwood 1997).

Apart from pottery comparisons, there are other similarities in material culture that support the WRM. The edge-ground stone tools at the Niah Caves, Sarawak, resemble those from Bacsonian sites in northern Vietnam, both dating back to the early Holocene (Bulbeck 2008; Rabett et al. 2013). Indonesia's Neolithic adzes include the pick-adze and shield-shaped types that are typical of western Indonesia and the shouldered-adze, stepped-adze, and violin-shaped types of eastern Indonesia (Heekeren 1972). In addition, ethnographic data reveal similar mouth organs in the western part of Kalimantan and MSEA, especially Vietnam. This type of instrument is considered indigenous to Southeast Asia, as it is not found in any other part of the world (Blench 2010).

Linguistic data provide another indication of the western migration route. Adelaar (1995) noted that the Aslian languages of Peninsular Malaysia, which belong to the Austroasiatic family, resemble the Land Dayak languages of Kalimantan in two ways: sharing an unusual phonological feature known as preplosion and sharing cognate words for dying and bathing. His preferred explanation for these similarities is that Land Dayak originated as the result of a language shift from Aslian to Austronesian or that both of the languages have a common sub-stratum inherited from an unknown language. Blench (2010) strengthened this perspective by noting further similarities between Aslian and the Dayak languages of Sarawak. Without ignoring the possibility of a shared legacy from ancestral Austric, we can note that neither Adelaar nor Blench advocated this explanation and instead preferred to invoke migration factors. Blench (2010), 
in particular, developed a case for language elements introduced by Austroasiatic agricultural communities that infiltrated ISEA during its pre-Austronesian period. Of central importance to his argument is the word for 'taro', which is phonologically similar between the Munda languages (Austroasiatic languages of northeast India) and the term reconstructed for Proto-MalayoPolynesian. The implication that taro was brought to ISEA by early Austroasiatic speakers, and absorbed by early Austronesians (along with the term for taro) when they reached Kalimantan and Palawan, is strengthened by the absence of a reconstruction of the term for taro in ProtoAustronesian or Proto-Malayo-Polynesian.

From taro we move onto the issue of animal domestication. The results of several studies suggest that the early domesticated pigs and chickens originated in MSEA before being introduced to ISEA as part of a Neolithic dispersal (Dobney et al. 2008). For example, ancient and modern DNA studies have demonstrated that a unique haplotype in Sus scrofa known as the 'Pacific Clade' appears to have its origins in Yunnan Province, China, and/or northern Vietnam and Laos where wild progenitors of this genetic lineage have been identified (Dobney et al. 2008; Larson et al. 2010). Translocation of this haplotype can be traced south through Vietnam, probably as part of the Austroasiatic human movements around 4000 BP (see Piper, Chapter 15, this volume). The dispersal continues through Peninsula Malaysia and western Indonesia, Nusa Tenggara and into the Pacific (Larson et al. 2007). Modern chicken genetic studies have indicated multiple domestication events between South Asia and Thailand (Fumihito et al. 1996; Liu et al. 2002; Storey et al. 2013), with Haplogroup D chickens potentially being introduced to ISEA via Peninsula Malaysia and western Indonesia. The presence of different and distinctive lineages of pigs and chickens in the Philippine archipelago argues against an Austronesian introduction of these domestic animals into ISEA (Larson et al. 2007; Blench 2010), and at present it appears that of all the potential domesticated animals (pig, dog and chicken) from Taiwan/Philippines, it is only the chicken that was dispersed more widely (Thomson et al. 2014).

Results from human genetic studies also support a Neolithic connection between western Indonesian and MSEA populations. One of these studies (Tumonggor et al. 2013) shows that western and eastern Indonesians form separate clusters within a general Indonesian cluster that falls together with Asian groups, away from Oceanic populations. Among these Asian groups, Indonesians cluster most closely with populations from Vietnam and the Philippines and more distantly with Taiwan populations. A recent genetic study (Lipson et al. 2014) goes so far as recognising distinct Austroasiatic and Austronesian nuclear DNA components. Both of these are similarly pronounced in the sampled western Indonesian populations and the Manggarai of Flores, but with the Austroasiatic component absent from other eastern Indonesian and from Philippine populations.

In addition, the study by Lipson et al. (2014) identifies a distinct 'Negrito' component for populations in the Philippines and a 'Melanesian' component for populations across Indonesia and Austronesian-speaking parts of the Pacific. The presence of the latter component in Indonesia may be related to evidence for the introduction of certain crops such as sugar cane and at least some types of banana, taro and yam from New Guinea into Indonesia prior to the Austronesian expansion (O'Connor 2015).

\section{Western Indonesia: Confluence of WRM and ERM}

The perspectives from the various studies outlined above, from archaeology, linguistics, ethnography, palaeobotany and genetics, clearly suggest an early connection between the western parts of Indonesia and MSEA, one that operated separately from any connection with the Philippines and Taiwan. Both of these connections were probably realised by migrations, 
which brought Neolithic culture into Indonesia. If recent studies have focused more on the Eastern Route Migration (ERM) that originated in Taiwan, there is currently evidence for a Western Route of Migration (WRM) that possibly originated in Indochina, specifically northern Vietnam. The WRM might have proceeded from Vietnam through Kalimantan as proposed by some scholars (Blench 2010), but it might also have proceeded through Peninsular Malaysia to enter western Indonesia (Anderson 2005). More research is needed to assess these alternative proposals.

This new outlook offers a better understanding of the origins and development of the Neolithic in Indonesia. The WRM evidence brings to light the point that the bearers of the Neolithic to Indonesia were not only Austronesian but probably also Austroasiatic speakers. They intertwined in developing a culture unknown to the previous inhabitants of ISEA, a culture that included sedentary living, domesticated animals and plants, the use of polishing in adze production and other stone tools, pottery and bark-cloth making. A distinctive characteristic of the two migration routes is the associated pottery, in particular the cord-marked and other paddle-impressed pottery associated with the WRM and the red-slipped pottery associated with the ERM. It also seems that the Neolithic Austronesians, judging by their vast dispersal area across the archipelago and on to Oceania, were more advanced in seafaring techniques than the Austroasiatic-speaking Neolithic immigrants.

One question that this new perspective raises is why every indigenous ethnic group in present-day western Indonesia speaks an Austronesian language. A preliminary answer to this question comes from the available radiometric datings older than 4000 BP of the Neolithic sites of Gua Sireh in Sarawak and Takengon in Aceh, which suggest that the WRM occurred earlier than the ERM. Considering the onset of the Neolithic in Peninsular Malaysia dated back to around 6500 BP (Bulbeck 2014), the early arrival of the Neolithic to ISEA is reasonable. The Austronesians, who arrived in Sulawesi at $c a .4000 \mathrm{BP}$, continued to migrate in different directions, and those who reached the western parts of Indonesia afterward (ca.3500-3000 BP or even later) enjoyed pre-eminence over the local cultures, resulting in the replacement of Austroasiatic or other languages.

To close my discussion, I would like to stress again that what I have presented here is still a preliminary insight into the Neolithic of Indonesia that needs to be enhanced by further research. Questions on how and when the western migration occurred, how far it dispersed in Indonesia, how the Austroasiatic and Austronesian groups with their linguistic differences interacted with each other in genetic and cultural terms, and how and why Austronesian languages came to dominate western Indonesia are challenges to be addressed in order to understand more on the cultural ancestors of Indonesians. A multidisciplinary approach is required to trace back the origins of the languages and biological affinities of Indonesia's ethnic groups, within the context of the Neolithic archaeology of Southeast Asia and its surrounds. In-depth research on those topics will hopefully reveal the origins of Indonesian ancestors, their regional and global interconnections, and their development from the beginning to the present day.

\section{Acknowledgements}

I wish to express my gratitude to Dr David Bulbeck from The Australian National University for his openhandedness to make suggestions and language corrections to this paper. I also would like to thank Dr Philip J. Piper for inviting me to contribute to this Festschrift. 


\section{References}

Adelaar, K.A. 1995. Borneo as a cross-roads for comparative Austronesian linguistics. In P. Bellwood, J.J. Fox and D. Tryon (eds), The Austronesians: Historical and Comparative Perspectives, pp. 75-95. Canberra: The Australian National University.

Anceaux, J.C. 1965. Linguistic theories about the Austronesian homeland. Bijdragen tot de Taal-, Landen Volkenkunde 121: 417-432. doi.org/10.1163/22134379-90002950.

Anderson, A. 2005. Crossing the Luzon Strait: archaeological chronology in the Batanes Islands, Philippines and the regional sequence of Neolithic dispersal. Journal of Austronesian Studies 1: 25-45.

Anggraeni, T. Simanjuntak, P. Bellwood and P.J. Piper. 2014. Neolithic foundations in the Karama valley, West Sulawesi, Indonesia. Antiquity 88: 740-756. doi.org/10.1017/S0003598X00050663.

Aziz, F.A. 2009. Laporan Penelitian Lolo Gedang, Kerinci. Unpublished research report. Jakarta: Pusat Penelitian Arkeologi Nasional.

Bellwood, P. 1978. Man's Conquest of the Pacific. Sydney: Collins.

—. 1984-1985. A hypothesis for Austronesian origins. Asian Perspectives 26: 107-117.

—. 1985. The Prehistory of the Indo-Malaysian Archipelago. Sydney: Academic Press.

1997. Prehistory of the Indo-Malaysian Archipelago. 2nd edition. Honolulu: University of Hawaii Press.

—. 2005. First Farmers: The Origins of Agricultural Societies. Oxford: Blackwell.

2006. Borneo as the homeland of Malay? The perspective from archaeology. In J.T. Collins and A. Sariyan (eds), Borneo and the Homeland of the Malays: Four Essays, pp. 45-63. Kuala Lumpur: Dewan Bahasa dan Pustaka.

Bellwood, P., J.J. Fox and D. Tryon. 1995. The Austronesians in history: Common origins and diverse transformations. In P. Bellwood, J.J. Fox and D. Tryon (eds), The Austronesians: Historical and Comparative Perspectives, pp. 3-13. Canberra: The Australian National University.

Bellwood, P., N. Goenadi, G. Irwin, A.W. Gunadi and D. Tanudirjo. 1998. 35,000 years of prehistory in the northern Moluccas. In G.J. Bartstra (ed.), Bird's Head Approaches. Irian Jaya Studies a Programme for Interdisiplinary Research, pp. 233-275. Rotterdam: A.A. Balkema.

Blench, R. 2010. Was there an Austroasiatic presence in Island Southeast Asia prior to the Austronesian expansion? Bulletin of the Indo-Pacific Prehistory Association 30: 133-144.

Blust, R. 1984-1985. The Austronesian homeland: a linguistic perspective. Asian Perspectives 26: 45-68.

Bulbeck, F.D. 1996-1997. The Bronze-Iron Age of South Sulawesi, Indonesia: Mortuary traditions, metallurgy and trade. In F.D. Bulbeck and N. Barnard (eds), Ancient Chinese and Southeast Asian Bronze Age Cultures, pp. 1007-1076. Taipei: SMC Publishing Inc.

- 2008. An integrated perspective on the Austronesian diaspora: The switch from cereal agriculture to maritime foraging in the colonisation of Island Southeast Asia. Australian Archaeology 67: 31-52. doi.org/10.1080/03122417.2008.11681877.

- 2014. The chronometric Holocene archaeological record of the Southern Thai-Malay peninsula. International Journal of Asia Pacific Studies 10(1): 111-162. 
Bulbeck, F.D. and Nasruddin. 2002. Recent insights on the chronology and ceramics of the Kalumpang site complex, South Sulawesi, Indonesia. Bulletin of the Indo-Pacific Prehistory Association 22: 83-100.

Chang, K.C. 1964. Prehistoric and early historic culture horizons and traditions in South China. Current Anthropology 5: 359-375. doi.org/10.1086/200525.

1970. Prehistoric archaeology of Taiwan. Asian Perspectives 13: 59-77.

Childe, V.G. 1936. Man Makes Himself. Oxford: Oxford University Press.

Dobney, K., T. Cucchi and G. Larson. 2008. The pigs of Island Southeast Asia and the Pacific: New evidence for taxonomic status and human-mediated dispersal. Asian Perspectives 47: 59-74. doi. org/10.1353/asi.2008.0009.

Duff, R. 1970. Stone Adzes of Southeast Asia: An Illustrated Typology. Christchurch: Canterbury Museum Bulletin.

Dyen, I. 1965. A Lexicostatistical Classification of the Austronesian Languages. International Journal of American Linguistic Memoir 19.

Fumihito, A., T. Miyake, M. Takada, R. Shingu, T. Endo, T. Gojobori, N. Kondo and S. Ohno. 1996. Monophyletic origin and unique dispersal patterns of domestic fowls. Proceedings of the National Academy of Sciences 93: 6792-6795. doi.org/10.1073/pnas.93.13.6792.

Galipaud, J.-C., A. Noury and L. Illouz. 2010. Le site archéologique de Pain Haka, District de Florès Timur, province de Nusa Tenggara Timur, Indonésie. Rapport d'évaluation du potential archéologique. Paris: Institut de recherche pour le développement.

Heekeren, H.R. van. 1950. Rapport over de ontgraving te Kamasi, Kalumpang (West Centraal Celebes). Oudheidkundig Verslag Oudheidkundige Dienst in Indonesië 1949, pp. 26-46. Bandung: A.C. Nix and Co.

. 1972. The Stone Age of Indonesia. 2nd edition. Verhandelingen van het Koninklijk Instituut voor Taal-, Land- en Volkenkunde 61. The Hague: Martinus Nijhoof.

Heine-Geldern, R. von. 1945. Prehistoric research in the Netherlands Indies. In P. Honig and F. Verdoorn (eds), Science and Scientists in the Netherlands Indies, pp. 129-162. New York: Board for Netherlands Indies, Surinam, and Curacao.

Jaafar, Z. 2003. Ancient Limestone Landscapes of Malaysia: An Archaeological Insight. Kuala Lumpur: Jabatan Muzium dan Antiquiti.

Jiao, T. 2004. The Neolithic cultures in Southeast China and the search for an Austronesian homeland. In V. Paz (ed.), Southeast Asian Archaeology. Wilhelm G. Solheim II Festschrift, pp. 565-588. Manila: University of the Philippines Press.

Larson, G., T. Cucchi, M. Fujita, E. Matisoo-Smith, J. Robins, A. Anderson, B. Rolett, M. Spriggs, G. Dolman, T.-H. Kim, N.T.D. Thuy, E. Randi, M. Doherty, A.D. Rokus, R. Bolt, T. Djubiantono, B. Griffin, M. Intoh, E. Keane, P. Kirch, K.-T. Li, M. Morwood, L.M. Pedriña, P.J. Piper, R.J. Rabett, P. Shooter, G. Van den Burgh, E. West, S. Wickler, J. Yuan, A. Cooper and K. Dobney. 2007. Phylogeny and ancient DNA of Sus provides new insights into Neolithic expansion in Island Southeast Asia and Oceania. Proceedings of the National Academy of Sciences 104(12): 4834-4839. doi.org/10.1073/pnas.0607753104. 
Larson, G., R. Liu, X. Zhao, J. Yuan, D. Fuller, L. Barton, K. Dobney, Q. Fan, Z. Gu, Z., X-H. Liu, Y. Luo, P. Lv, L. Andersson and N. Li. 2010. Patterns of East Asian pig domestication, migration, and turnover revealed by modern and ancient DNA. Proceedings of the National Academy of Sciences 107(17): 7686-7691. doi.org/10.1073/pnas.0912264107.

Lipson, M., P.-R. Loh, N. Patterson, P. Moorjani, Y.-C. Ko, M. Stoneking, B. Berger and D. Reich. 2014. Reconstructing Austronesian population history in Island Southeast Asia. Nature Communication 5, Article no. 4689, doi: 10/1038/incomms5689.

Liu, Y.-P., G.-S. Wu, Y.-G. Yao, Y.-M. Miao, G. Luikart, M. Baig, A. Beja-Pereira, Z.-L, Ding, M. Gounder Palanichamy and Y.-P. Zhang. 2002. Multiple maternal origins of chickens: Out of the Asian jungles. Molecular Phylogenetics and Evolution 38: 12-19. doi.org/10.1016/j. ympev.2005.09.014.

Masanari, N. and N. Kim Dung. 2002. Excavation of An Son: A Neolithic mound site in the middle reach of the Vam Co Dong River, southern Vietnam. Bulletin of the Indo-Pacific Prehistory Association 22: 101-109.

Meacham, W. 1984-1985. On the improbability of Austronesian origins in South China. Asian Perspectives 26: 89-106.

1999. Neolithic to historic in the Hong Kong region. Bulletin of the Indo-Pacific Prehistory Association 18: 121-127.

Noerwidi, S. 2009. Archaeological research at Kendeng Lembu, East Java, Indonesia. Bulletin of the Indo-Pacific Prehistory Association 29: 26-32. doi.org/10.7152/bippa.v29i0.9474.

O'Connor, S. 2015. Rethinking the Neolithic in Island Southeast Asia, with particular reference to the archaeology of Timor Leste and Sulawesi. Archipel 90: 15-47.

Oppenheimer, S. 1998. Eden in the East: The Drowned Continent of Southeast Asia. London: Weidenfeld and Nicolson.

Oppenheimer, S. and M. Richards. 2001. Fast trains, slow boats, and the ancestry of the Polynesian Islanders. Science Progress 84: 157-181. doi.org/10.3184/003685001783238989.

Plutniak, S., A.A. Oktaviana, B. Sugiyanto, J.-M. Chazine and F.-X. Ricaut. 2014. New Ceramic Data from East Kalimantan: The cord-marked and red-slipped sherds of Liang Abu's layer 2 and Kalimantan's pottery chronology. Journal of Pacific Archaeology 5(1): 90-99.

Rabett, R.J., G. Barker, H. Barton, C. Hunt, L. Lloyd-Smith, V. Paz, P.J. Piper, R. Premathilake, G. Rushworth, M. Stephens and K. Szabó. 2013. Landscape transformations and human responses c. 11,500-4500 years ago. In G. Barker (ed.), Rainforest Foraging and Farming in Island Southeast Asia, pp. 217-253. Cambridge: McDonald Institute for Archaeological Research.

Simanjuntak, T. 1992. Neolitik di Indonesia, neraca dan perspektif penelitian. Jurnal Arkeologi Indonesia 1: $117-130$.

— (ed.). 2008. Austronesian in Sulawesi. Jakarta: Center for Prehistoric and Austronesian Studies.

— 2013. Asal usul dan diáspora penutur Austronesia. Paper presented at the seminar 'Austronesia Dispersal: Gene, Language, and Civilization', Medan.

Simanjuntak, T., R. Fauzi, J.-C. Galipaud, F.A. Aziz and H. Buckley. 2012. Prasejarah Austronesia di Nusa Tenggara. Sebuah Pandangan awal. Amerta 30: 73-89.

Solheim, W.G. II. 1984-1985. The Nusantao hypothesis. Asian Perspectives 26: 77-88. 
Spriggs, M. 1989. The dating of the island Southeast Asian Neolithic: An attempt at chronometric hygiene and linguistic correlation. Antiquity 63: 587-613. doi.org/10.1017/S0003598X00076560.

- 2011. Archaeology and the Austronesian expansion: Where are we now? Antiquity 85: 510-528. doi.org/10.1017/S0003598X00067910.

Stein Callenfels, P.V. van. 1926. Bijdrage tot de chronologie van het neolithicum in Zuid-Oost Azie. Oudheidkundige Verslag 1926, pp. 174-180. Batavia (Jakarta): Oudheidkundige Dienst in Nederland Indie.

Storey, A.A., D. Quiroz, N. Beavan, and E. Matisoo-Smith. 2013. Polynesian chickens in the New World: A detailed application of a commensal approach. Archaeology in Oceania 42(2): 101-119. doi. org/10.1002/arco.5007.

Sutayasa, I.M. 1972. Notes on the Buni pottery complex, northwest Java. Mankind 8: 182-184.

Tanudirjo, D.A. 2001. Islands in Between: Prehistory of the Northeastern Indonesia Archipelago. Unpublished PhD thesis, Department of Archaeology and Anthropology, The Australian National University, Canberra.

Tanudirjo, D.A. and T. Simanjuntak. 2004. Indonesia di tengah debat asal-usul masyarakat Austronesia. In Polemik Tentang Masyarakat Austronesia. Fakta atau fiksi?, pp. 11-32. Jakarta: Lembaga Ilmu Pengetahuan Indonesia.

Thomson, V.A., O. Lebrasseur, J.J. Austin, T.L. Hunt, D.A. Burney, T. Denham, N.J. Rawlence, J.R. Wood, J. Gongora, L.G. Flink, A. Linderhom, K. Dobney, G. Larson and A. Cooper. 2014. Using ancient DNA to study the origins and dispersal of ancestral Polynesian chickens across the Pacific Proceedings of the National Academy of Sciences 111(35): 4826-4831.

Tumonggor, M.K., T.M. Karafet, B. Hallmark, J.S. Lansing, M.F. Hammer and M.P. Cox. 2013. The Indonesian archipelago: an ancient genetic highway linking Asia and the Pacific. Journal of Human Genetics 58: 165-173. doi.org/10.1038/jhg.2012.154.

Wiradnyana, K. and S. Taufikurrahman. 2011. Gayo Merangkai Identitas. Jakarta: Yayasan Pustaka Obor Indonesia. 
This text is taken from New Perspectives in Southeast Asian and Pacific Prehistory, edited by Philip J. Piper, Hirofumi Matsumura and David Bulbeck, published 2017 by ANU Press, The Australian National University, Canberra, Australia. 